\title{
Populasi dan struktur komposisi vegetasi habitat bunga bangkai (Amorphophallus titanum [Becc.] Becc. Ex Arcang) di kawasan hutan Bengkulu
}

\section{Population and composition structure of Titan Arum habitats (Amorphophallus titanum [Becc.] Becc. Ex Arcang) in lowland tropical rainforests of Bengkulu}

Wahyudi Arianto ${ }^{\mathrm{a}}$, Ervizal AM Zuhud ${ }^{\mathrm{b}}$, Agus Hikmat $^{\mathrm{b}}$, Tutut Sunarminto ${ }^{\mathrm{b}}$, Iskandar Z Siregar ${ }^{\mathrm{c}}$

a Jurusan Kehutanan Fakultas Pertanian, Universitas Bengkulu, Kota Bengkulu, 38122, Indonesia

${ }^{b}$ Departemen Konservasi Sumberdaya Hutan dan Ekowisata, Fakultas Kehutanan, Institut Pertanian Bogor, Bogor,

16680, Indonesia

cDepartemen Silvikultur, Fakultas Kehutanan, Institut Pertanian Bogor, Bogor, 16680, Indonesia

Article Info:

Received: 18 - 02 - 2018

Accepted: 27 - 04 - 2018

Keywords:

Amorphophallus titanum, diversity index, evenness index, interspecific association, important value index, population, structure and composition.

Corresponding Author: Wahyudi Arianto Jurusan Kehutanan Fakultas Pertanian, Universitas Bengkulu, Kota Bengkulu;

Email: warianto@unib.ac.id

\begin{abstract}
The knowledge of structure and composition of Titan Arum habitats in lowland tropical rainforests of Bengkulu limit the option to formulate the appropriate strategy for conservation. The research was carried out with the objective to determine the population, structure, and composition of vegetation in the habitats of Titan arum located in Bengkulu. This study used purposively sampled plot with a size of $100 \mathrm{~m} \times 100 \mathrm{~m}$ consisting of sub-plot of $20 m \times 20 m, 10 m \times 10 m, 5 m \times 5 m$ and $2 m \times 2 m$ for observing tree, pole, sapling, and seedling. Data were analyzed to generate the following parameters: important value index (IV), diversity index of Shannon-Wienner and evenness index, interspecific association and resemblance function. The results showed that the total num-ber of Titan Arum individuals found across three sampled forest sites were 52 individuals, consisting of 49 individuals at the vegetative phase and three individuals at generative phase. Titan Arum habitats consisted of 417 species belonging to 103 families of various growth stages. Habitat in Air Selimang was dominated by Artocarpus elasticus with an important value index of 12.09\%, while in Tebat Monok and Palak Siring were by Quercus oidocarpa with IV of $22.22 \%$ and Elatoriospermum tapos with IV of $31.40 \%$, respectively. Values of diversity indices $\left(H^{\prime}\right)$ of vegetation for Titan Arum habitats for each growth stages were nearly steady $(2.75-$ 4.50). A similar steady trend was also observed for evenness index values of 0.640 - 0.982 at each growth stages. The vegetation of Titan Arum in Air Selimang and Tebat Monok revealed positive interspecific association for all species, whereas in the Palak Siring habitat showed independence of species. Air Selimang Vegetation has the greatest resemblance to Te-bat Monok with a similarity index of 62.26 .
\end{abstract}

How to cite (CSE Style $8^{\text {th }}$ Edition):

Arianto W, Zuhud EAM, Hikmat A, Sunarminto T, Siregar IZ. 2019. Populasi dan struktur komposisi vegetasi habitat bunga bangkai (Amorphophallus titanum [Becc.] Becc. Ex Arcang) di kawasan hutan Bengkulu. JPSL 9(2): $241-257$. http://dx.doi.org/10.29244/jps1.9.2. 241-257.

\section{PENDAHULUAN}

\section{Latar Belakang}

Bunga bangkai (Amorphophallus titanum [Becc.] Becc. Ex Arcang) merupakan salah satu tumbuhan yang mempunyai perbungaan tertinggi di dunia. Ukuran tinggi bunga bangkai ini berkisar $1.6-3 \mathrm{~m}$ (Arianto et al. 
1999; Barthlott dan Lobin 1998; Giardano 1999). Tanaman ini pertama kali dikenal dalam dunia ilmu pengetahuan setelah ditemukan oleh Dr.Odoardo Beccari pada tahun 1878 di daerah Lembah Anai, Sumatera Barat (Hetter-scheid dan Ittenbach 1996). Spesies ini digolongkan sebagai tumbuhan endemik yang hanya di temukan pada kawasan hutan di Pulau Sumatera (Barthlott dan Lobin 1998; Hidayat dan Yuzammi 2008; Yuzammi et al. 2017). Bunga bangkai dijadikan simbol dan menjadi spesies bendera pada banyak kebun botani di dunia sebagai usaha untuk menarik sebanyak mungkin pengunjung ke kebun botani (Latifah dan Purwantoro 2015). Tumbuhan ini menarik banyak orang karena bentuk perbungaan unik yang mengeluarkan bau busuk, keunikan siklus biolog-inya dan status kelangkaannya.

Secara alami A. titanum tersebar di hutan hujan Sumatera sebagai tumbuhan bawah kanopi ("undergrowth") pada tanah berkapur, namun tumbuhan ini ditemukan juga di tempat terbuka, hutan sekunder, pinggir jalan, ping-gir sungai, atau di tepi hutan. A. titanum memiliki tiga siklus hidup yang jelas, yaitu: tahap vegetatif, dorman, dan generatif. Siklus vegetatif terutama untuk pertumbuhan umbi yang dapat mencapai bobot hingga $100 \mathrm{~kg}$. Siklus ini dimulai pada awal musim hujan dengan dihasilkannya satu daun tunggal yang besar, dan berlangsung selama 6-12 bulan, dilanjutkan siklus dorman selama 1-4 tahun sebelum memasuki siklus pembungaan. Siklus pembungaan umumnya tidak teratur (Bown 1988; Graham dan Hadiah 2004; Hetterscheid dan Ittenbach 1996).

A. titanum telah ditetapkan sebagai tumbuhan yang di lindungi di Indonesia menurut Peraturan Pemerintah Nomor 7 Tahun 1999 (Lampiran PP. No. 7/1999). Berdasarkan IUCN Red List of Threatened plant edisi 1997, A. titanum digolongkan ke dalam Vulnerable (V) Namun pada tahun 2002 spesies ini justru dikeluarkan dari daftar IUCN karena belum tersedianya data yang komprehensip mengenai populasi dan keberadaannya di alam. Tidak adanya data tentang kondisi populasi bunga bangkai di habitat alaminya tercermin sedikitnya penelitian yang di lakukan di lapangan.

Penurunan populasi A.titanum di kawasan hutan Bengkulu dapat dipastikan akibat konversi lahan hutan yang menjadi habitat A.titanum. Berdasarkan data dari Dinas Kehutanan Provinsi Bengkulu, perambahan kawasan hutan tidak hanya terjadi di hutan produksi tetapi juga terjadi di hutan lindung maupun hutan konservasi. Luas penutupan lahan di dalam kawasan hutan berdasarkan penafsiran citra satelit sampai dengan tahun 2012 dan lansat ETM, menunjukkan bahwa dari total luas kawasan hutan di Provinsi Bengkulu 924600 ha yang masih berhutan sebesar 74.84\% (692 000 ha) dan non hutan sebesar $25.16 \%$ (232 700 ha) (Kementerian Kehutanan 2014).

Pada umumnya penelitian A.titanum dilakukan pada skala rumah kaca di kebun-kebun botani di dunia ( Bonn Jerman, Italia, Amerika, Jepang, Australia dan negara-negara lain). Penelitian-penelitian yang telah dilakukan skala rumah kaca kebun botani dan laboratorium antara lain adalah kajian morfologi, anatomi, pertumbuhan vegetatif dan generatif/spathe dan spadik (Barthlott dan Lobin 1998; Lobin et al. 2007; Sholihin dan Purwantoro 2005; Purwanto dan Latifah 2013; Gandawijaja et al. 1983; Claudel et al. 2012; Hejnowicz dan Barthlott 2005), thermogenesis (Barthlott et al. 2009), analisis bau bunga (Fujioka et al. 2012), perkecambahan (Latifah dan Purwantoro 2015), mikro propagasi (Irawati 2011), pendugaan keragaman genetika pada beberapa populasi (Poerba dan Yuzammi 2008).

Kondisi ini bertolak belakang dengan penelitian A.titanum pada habitat alaminya yang jumlahnya sangat sedikit. Penelitian pada habitat alaminya yang telah dilakukan antara lain oleh Giardano (1999) di Sumatera Barat yang dilakukan tahun 1994 -1995 dan Hidayat dan Yuzami (2008), di beberapa lokasi di daerah Kepahiang. Berdasarkan penelitian dan survey pendahuluan menunjukkan ada kecendrungan sedang terjadi penurunan populasi di alam (Hidayat dan Yuzammi 2008). Bila kondisi ini dibiarkan terus menerus akan berakibat keberadaan spesies ini akan terancam. Penurunan populasi bunga bangkai disebabkan faktor internal (aspek biologis) dan faktor eksternal (gangguan dan kerusakan habitat). Namun, masih banyak aspek penelitian di habitat alam yang belum dilakukan, sehingga menyulitkan penyusunan rekomendasi dan strategi konservasi jenis ini mengingat aspek spesifik habitat yang sangat menentukan keberadaan populasinya. 


\section{Tujuan}

Berdasarkan uraian yang telah disebutkan maka tujuan penelitian ini adalah untuk mengkarakterisasi populasi dan struktur komposisi vegetasi habitat bunga bangkai (A. titanum) untuk menduga parameter utama populasi dan habitat, yaitu kepadatan populasi bunga bangkai dan pola sebaran, komposisi vegetasi dan kelimpahan, keanekaragaman spesies dan kemerataan, asosiasi interspesifik dan kemiripan vegetasi antar lokasi.

\section{METODE PENELITIAN}

\section{Tempat dan waktu Penelitian}

Penelitian ini dilakukan pada 3 (tiga) lokasi kawasan hutan di Provinsi Bengkulu (Tebat Monok, Air Selimang dan Palak Siring). Penetapan lokasi sebagai sub-populasi didasarkan pada hasil penelitian terdahulu. Penelitian ini dilakukan selama 12 bulan, dari bulan September 2016 sampai dengan Bulan September 2017.

\section{Metode Pengumpulan Data}

\section{Populasi A. titanum dan Sebaran spasial di Bengkulu}

Untuk melihat kondisi populasi bunga bangkai di lakukan pengamatan pada plot ukuran $20 \mathrm{~m}$ x $20 \mathrm{~m}$. Penentuan pola distribusi tumbuhan bunga bangkai dilakukan dengan menggunakan metoda Indeks Penyebaran Morisita (Ludwig dan Reynold 1988). Penentuan sebaran dilakukan dengan tahapan sebagai berikut: i) Menghitung indeks dispersi Morisita , ii) Standarisasi.

\section{Struktur dan komposisi vegetasi habitat A. titanum}

Kajian habitat A. titanum dilakukan dengan menggunakan metode purposive sampling dengan luasan petak $1 \mathrm{ha}$ /lokasi dan berbentuk bujursangkar yang diambil pada plot yang menunjukkan keberadaaan A. titanum. Data yang diambil berupa data biotik kondisi populasi A. titanum. Peletakan plot dan sub plot dilakukan secara bersarang (nasted plot). Kategori pengelompokan vegetasi dan luas petak ukur disajikan pada Tabel 1 .

\section{Identifikasi Spesies}

Identifikasi spesies A.titanum dan tumbuhan dilakukan langsung di lapang dengan bantuan pemandu lapan-gan. Tumbuhan yang belum diketahui jenisnya dijadikan herbarium dan selanjutnya diidentifikasi baik di Herbar-ium Universitas Bengkulu (HUB) ( $\mathrm{n}= \pm 500$ lembar spesimen) dan Herbarium Bogoriense (BO) $(\mathrm{n}= \pm 900$ lembar spesimen).

Tabel 1 Kategori pengelompokan vegetasi, luas petak ukur dan jumlah plot total

\begin{tabular}{cccc}
\hline Tingkat pertumbuhan & Kriteria dimensi & Luas petak ukur (ha) & Jumlah plot \\
\hline Pohon & $\varnothing>20 \mathrm{~cm}$ & $20 \mathrm{~m} \times 20 \mathrm{~m}$ & 75 \\
Tiang & $\varnothing 10-19 \mathrm{~cm}$ & $10 \mathrm{~m} \times 10 \mathrm{~m}$ & 75 \\
Pancang & Tinggi $>1.5 \mathrm{~m}$ & $5 \mathrm{~m} \times 5 \mathrm{~m}$ & 75 \\
& $\varnothing<10 \mathrm{~cm}$ & $2 \mathrm{~m} \times 2 \mathrm{~m}$ & 75 \\
\hline
\end{tabular}

\section{Analisis Data}

Pola sebaran spesies tumbuhan bunga bangkai pada suatu komunitas tumbuhan menggunakan indeks Morisita. Persamaan Yang digunakan adalah sebagai berikut :

Keterangan :

$$
\operatorname{Id}=\mathrm{n} \frac{\left(\sum x^{2}-\sum x\right)}{\left(\sum x\right)^{2}-\sum x}
$$

Id : Derajat Penyebaran Morisita

$\mathrm{N}$ : Jumlah Petak Ukur 
$\sum x^{2}:$ Jumlah kuadrat dari total individu suatu spesies pada suatu komunitas

$\sum x$ : Jumlah total individu suatu spesies pada suatu komunitas

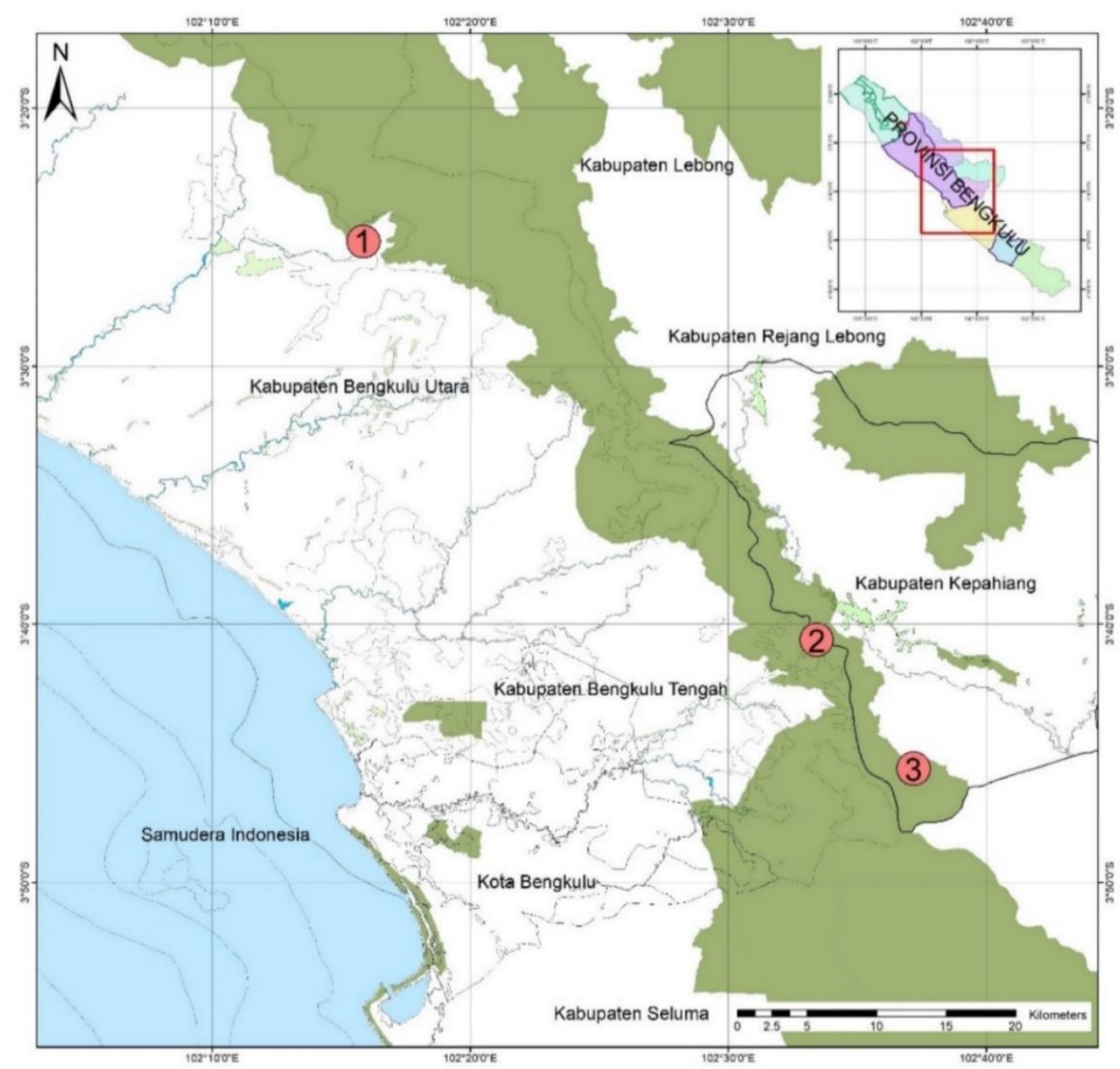

Gambar 1 Lokasi penelitian bunga bangkai (Amorphophallus titanum) di Kawasan hutan Provinsi Bengkulu:

Lokasi 1, Palak Siring (325'14.05 "S, 102 $15^{\prime} 48.51^{\prime \prime}$ E), Lokasi 2, Tebat Monok (340'16,98 "S,

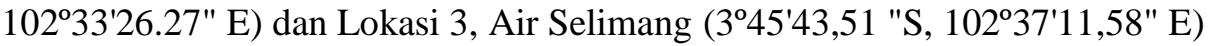

Selanjutnya dilakukan Uji Chi-square dengan menggunakan persamaan :

1. Derajat keseragaman

$$
\mathrm{Mu}=\frac{\left(x^{2} 0.975-n+\sum x_{i}\right)}{\left(\sum x_{i}\right)-1}
$$

Keterangan :

$\mathrm{Mu} \quad$ : Derajad Keseragaman

$x^{2} 0.975$ : Nilai Chi-square dari table dengan db (n-1), selang kepercayaan 97,5\%

$\sum x_{i} \quad$ : Jumlah Individu dari suatu spesies pada petak ukur ke-i

$n \quad$ : Jumlah Petak Ukur

2. Derajad Pengelompokan

$$
\mathrm{Mc}=\frac{\left(x^{2} 0.025-n+\sum x_{i}\right)}{\left(\sum x_{i}\right)-1}
$$

Keterangan :

Mc : Derajad pengelompokan

$x^{2} 0.025$ : Nilai Chi-square dari table dengan db (n-1), selang kepercayaan 2,5\%

$\sum x_{i} \quad$ : Jumlah Individu dari suatu spesies pada petak ukur ke-i 
n : Jumlah Petak Ukur

Standar derajat Morisita (Ip) dihitung dengan menggunakan empat persamaan pada salah satu kondisi berikut:

- Apabila Id $\geq M c>1$ maka dihitung: Ip $=0.5+0.5\left(\frac{I d-M c}{n-M c}\right)$

- Apabila Id $>M c \geq 1$ maka dihitung: Ip $=0.5\left(\frac{I d-M c}{M c-1}\right)$

- Apabila Id >Mc> 1 maka dihitung: Ip $=00.5\left(\frac{I d-M u}{M u-1}\right)$

- Apabila $1>\mathrm{Mu}>1$ maka dihitung: $\mathrm{Ip}=0.5+0.5\left(\frac{I d-M u}{M u}\right)$

Standar derajat Morisita (Ip) mempunyai interval -1.0 sampai 1.0 dengan taraf kepercayaan 95\% pada batas 0.5 dan -0.5 . Nilai Ip digunakan untuk menunjukkan kecendrungan pola penyebaran spesies tumbuhan bunga bangkai pada 3 lokasi di wilayah studi dengan selang nilai :

- $\mathrm{Ip}=0$, menunjukkan pola sebaran acak(random)

- Ip>0, menunjukkan pola sebaran menglompok(clumped)

- Ip $<0$, menunjukkan pola sebaran seragam(uniform)

Analisis vegetasi dilakukan untuk mengkarakterisasi struktur dan komposisi jenis dengan menggunakan perhitungan menurut Mueller-Dombois dan Ellenberg (1974), analisis habitat untuk menguraikan struktur dan komposisi menggunakan perhitungan sebagai berikut:

Kerapatan $=\frac{\text { Jumlah individu suatu spesies }}{\text { Luas Unit Contoh }}$

Kerapatan Relatif $(\mathrm{KR})=\frac{\text { Kerapatan } \text { suatu spesies }}{\text { Kerapatan total } \text { spesies }} \mathrm{X} 100 \%$

Frekuensi $=\frac{\text { Jumlah } \text { plot ditemukan suatu spesies }}{\text { total jumlah plot }}$

Frekuensi Relatif $(\mathrm{FR})=\frac{\text { Frekuensi } \text { suatu spesies }}{\text { Frekuensi total }} \mathrm{X} 100 \%$

Dominasi $=\frac{\text { Luas Bidang Dasar suatu spesies }}{\text { Luas Unit Contoh }}$

Dominasi Relatif $(\mathrm{DR})=\frac{\text { Dominasi suatu spesies }}{\text { Dominasi Seluruh spesies }} \mathrm{X} 100 \%$

Indeks Nilai Penting (Pohon dan Tiang) INP $=$ KR + FR + DR

Indeks Nilai Penting (Semai, Pancang, Tumbuhan Bawah) INP= KR + FR

Untuk melihat keanekaragaman spesies tumbuhan dalam plot pengamatan A.titanum menggunakan indeka keanekaragaman Shannon-Wiener, (Ludwig dan Reynold 1988). Indeks keragaman dari ShannonWiener adalah sebagai berikut

$$
\mathrm{H}^{\prime}=\sum_{i=1}^{S}\left[\left(\frac{n i}{N}\right) \operatorname{Ln}\left(\frac{n i}{N}\right)\right]
$$

Dimana :

$\mathrm{H}^{\prime}=$ Indeks keragaman Shannon-Wiener

$\mathrm{S}=$ Jumlah spesies

$\mathrm{Ni}=$ Jumlah individu spesies-i

$\mathrm{N}=$ Total jumlah individu semua spesies

Untuk mengetahui besarnya kemerataan spesies tumbuhan digunakan indeks Evenness (Ludwig dan Reynold 1988) sebagai berikut : 


$$
\mathrm{E} \mathrm{I}=\frac{H^{\prime}}{\ln (S)}=\frac{\operatorname{In}(N 1)}{\operatorname{In}(N o)}
$$

$\mathrm{Ni}=e^{1.33}=3.78$

Dimana :

EI= Indeks Evenness

$\mathrm{S}=$ Jumlah Spesies

Asosiasi interspesifik untuk kasus banyak spesies menggunakan persamaan berikut :

Dimana : pi $=$ ni/N

$$
\sigma_{T}^{2}=\sum_{i=1}^{S} p i(1-p i)
$$

$$
\mathrm{S}_{T}^{2}=\frac{1}{N} \sum_{j=1}^{N}\left(T_{j}-t\right)^{2}
$$

$\mathrm{T}=$ rata-rata jumlah spesies persampel

Setelah itu dihitung Varian rasio (VR)

$$
\mathrm{VR}=\frac{\mathrm{S}_{T}^{2}}{\sigma_{T}^{2}}
$$

VR merupakan indeks asosiasi antar seluruh spesies. Jika VR=1 (tidak ada asosiasi),jika VR >1 (seluruh spesies menunjukkan asosiasi positif) dan $\mathrm{VR}<1$ ( asosiasi negatif)

Jika nilai $\mathrm{W}$ terletak pada batas distribusi chi-square dengan kemungkinan 90\%, maka menerima hipotesis bahwa tidak ada asosiasi spesies

$$
\mathrm{X}^{2} 0,5 \mathrm{~N}<\mathrm{W}<\mathrm{X}^{2} 0,95 \mathrm{~N}
$$

Analisis kesamaan komunitas dilakukan dengan menggunakan Ward's minimum variance method (Romersburg 1984) dengan bantuan software Minitab 17 versi 17.3.1.

\section{HASIL PEMBAHASAN}

\section{Kepadatan populasi bunga bangkai dan pola sebaran}

Berdasarkan hasil penelitian serta pembahasan yang dijabarkan secara detail dapat ditarik kesimpulan. Karbon aktif menunjukkan efektif mengolah keluaran air limbah dan mampu menurunkan COD dengan persentase kemampuan rata-rata 96\%, kemampuan menurunkan TSS 92\% dan warna $98 \%$. Waktu jenuh 8 hari. Biaya yang dibutuhkan untuk mengolah air effluent dengan desain $12.5 \mathrm{~m}^{3} / \mathrm{jam}$, masa operasi $8-10$ jam perhari, adalah 3828 rupiah per $\mathrm{m}^{3}$. Biaya pembelian air baku PDAM untuk proses industri 12000 per $^{3}$, menunjukkan penghematan biaya hingga 8000 rupiah per meter kubik.

Hasil penelitian menunjukkan bahwa jumlah total individu bunga bangkai di 3 lokasi penelitian adalah 52 individu, yang terdiri atas 49 individu (fase vegetatif) dan 3 individu ditemukan pada fase generatif (Gambar 2). Lokasi yang paling banyak ditemukan jumlah individu bunga bangkai adalah Air Selimang yaitu 27 individu, yang ditemukan pada10 plot dari 25 plot yang diamati. Seluruh Individu bunga bangkai di Air Selimang ditemukan pada fase vegetatif. Hasil penelitian Hidayat dan Yuzammi (2008), di lokasi Air Ketapang, Bukit Jufi, Air Terjun Datar Lebar ditemukan 12 individu dewasa dan 22 individu anakan. Jumlah individu bunga bangkai di Air Selimang lebih banyak dibandingan dengan hasil penelitian Hidayat dan Yuzammi (2008). Lokasi yang paling sedikit ditemukan bunga bangkai adalah di Tebat Monok, hanya ditemukan 3 individu. Hasil pengamatan disekitar lokasi penelitian menunjukkan bahwa areal hutannya sudah banyak dikonversi menjadi kebun kopi khususnya di Air Selimang dan Tebat Monok. Perbedaan jumlah individu populasi bunga bangkai yang ditemukan ini diduga dipengaruhi oleh perbedaan ukuran plot pengamatan dan gangguan habitat. 


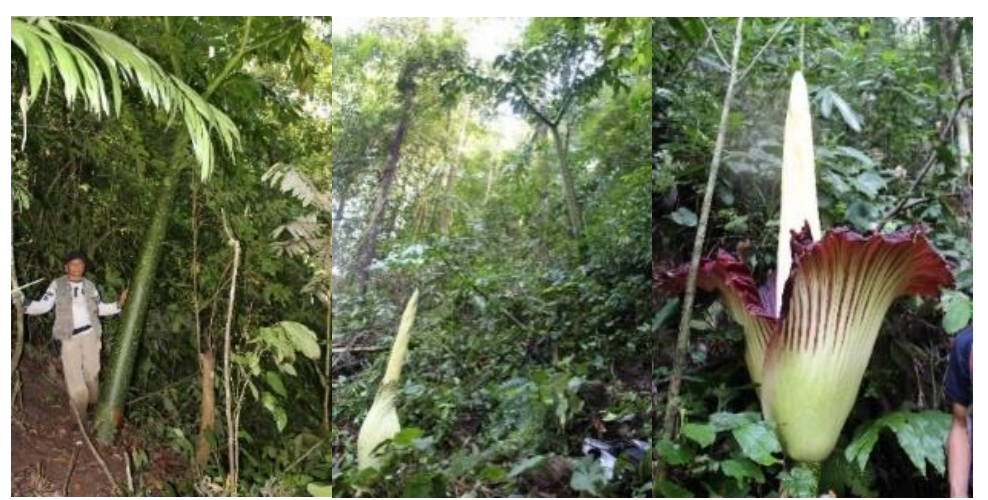

Gambar 2 Bunga bangkai yang ditemukan pada fase vegetatif dan generatif

Populasi bunga bangkai di areal penelitian di kelompokkan atas 6 kelas diameter batang (Gambar 3). Jumlah individu yang paling banyak ditemukan pada kelas diameter batang $0.15 \mathrm{~cm}-4.74 \mathrm{~cm}$ yaitu 26 individu. Gambar 3 menunjukkan bahwa adanya kecenderungan semakin besar ukuran diameter batang bunga bangkai, semakin sedikit jumlah individunya.

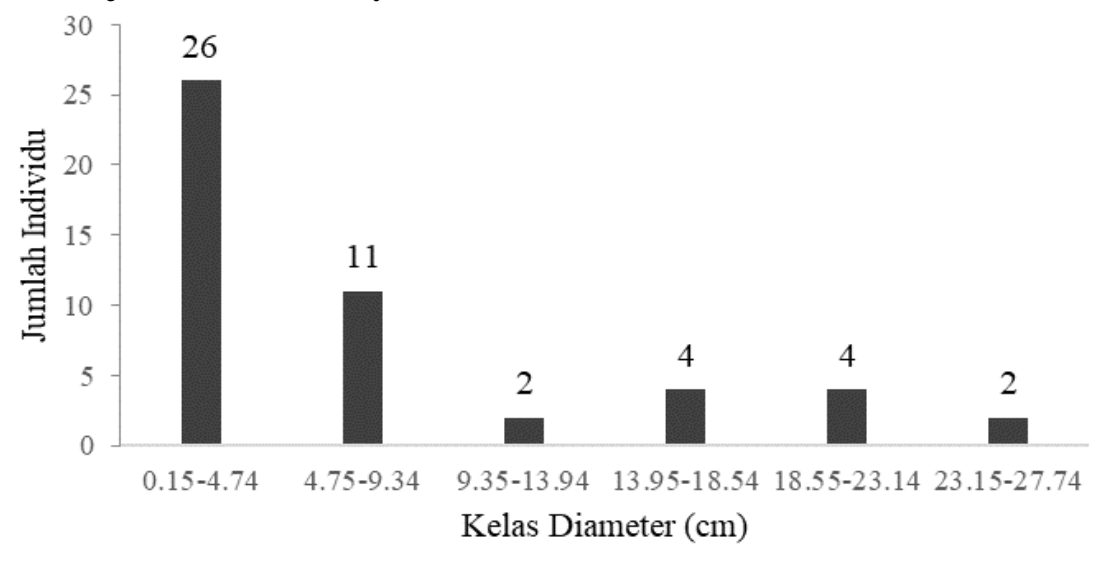

Gambar 3 Kelas Diameter batang bunga bangkai

Kondisi struktur tersebut merupakan fenomena alamiah untuk populasi di alam. Hasil penelitian Hidayat dan Yuzammi (2008) menunjukkan pola yang relatif sama, jumlah populasi anakan lebih banyak dari pada individu dewasa.

Hasil analisis pola penyebaran bunga bangkai menggunakan indeks Morisita disajikan pada Tabel 2 berikut ini.

Tabel 2 Pola distribusi spasial bunga bangkai (A.titanum) pada 3 lokasi yang berbeda

\begin{tabular}{ccccccc}
\hline No & Lokasi & $\begin{array}{c}\text { Indeks } \\
\text { Penyebaran } \\
\text { Morisita (Id) }\end{array}$ & $\begin{array}{c}\text { Uniform Index } \\
(\mathrm{Mu})\end{array}$ & $\begin{array}{c}\text { Clumped Index } \\
(\mathrm{Mc})\end{array}$ & $\begin{array}{c}\text { Indeks } \\
\text { Morisita } \\
\text { terstandar } \\
(\mathrm{Ip})\end{array}$ & Pola Penyebaran \\
\hline 1 & Air Selimang & 3.49 & 0.55 & 1.59 & 1.42 & Mengelompok \\
2 & Palak Siring & 11.84 & 0.39 & 1.81 & 5.48 & Mengelompok \\
3 & Tebat Monok & 8.33 & -2.87 & 6.12 & 1.48 & Mengelompok \\
\hline
\end{tabular}

Berdasarkan hasil analisis menunjukkan bahwa seluruh populasi bunga bangkai mempunyai pola penyebaran berkelompok. Sebaran mengelompok ini menandakan keberadaan individu pada suatu titik akan meningkatkan peluang adanya individu yang sama pada suatu titik yang lain didekatnya (McNaughton dan Wolf 1990). Hasil yang sama juga dilaporkan oleh Hidayat dan Yuzammi (2008) bahwa penyebaran bunga bangkai mengelompok. Penyebaran mengelompok ini kemungkinan disebabkan oleh gaya gravitasi dan aliran air di lantai hutan yang membawa biji bunga bangkai di lantai hutan. Menurut Hutchinson (1953), pola sebaran 
spasial komunitas di sebabkan oleh beberapa faktor yaitu: (1) Faktor vektorial, merupakan disebabkan sebagai kekuatan eksternal lingkungan (misalnya Angin, aliran air dan intensitas cahaya), (2) Faktor Reproduktif, disebabkan oleh mode reproduktif (kloning dan keturunan generasi), (3) Faktor sosial merupakan prilaku bawaan (tingkah laku territorial), (4) Faktor koaktif merupakan hasil dari interaksi intraspesifik (kompetisi), dan (5) Faktor stokastik merupakan hasil dari variasi acak dari factor-faktor sebelumnya (faktor vektorial, reproduktif, sosial dan koaktif). Kondisi sebaran mengelompok mengambarkan, bunga bangkai relatif mempuyai habitat yang sama.

Distribusi spasial suatu populasi berhubungan dengan kekhususan fisiologis untuk faktor-faktor lingkungan yang terbatas pada bagian suatu gradien. Sampai saat ini para ahli menyebutkan penyebaran bunga bangkai di bantu oleh burung rangkong (Barthlott dan Lobin 1998; Hidayat dan Yuzammi 2008). Pendapat ini relatif keliru, selama pengamatan di lapangan khususnya bunga yang sudah menghasilkan buah, tidak ditemukan sama sekali aktivitas burung rangkong sebagai pemencar biji bunga bangkai. Hal ini diperkuat oleh pendapat Poonswad et al (2013) dan Poonswad (1998) 6 jenis burung rangkong yang terdapat di Sumatera, jenis tumbuhan yang digunakan sebagai sumber makanannya adalah Oncosperma horridum (Arecaceae), Litsea spp (Lauraceae), Aglaia spectabilis, Chisocheton ceramicus (Meliaceae), Horsfieldia tomentosa, Myristica elliptica (Myristicaceae), Sterculia sp (Sterculiaceae) dan tidak satupun literatur yang menyebutkan sumber pakannya buah dari bunga bangkai (A.titanum). Secara ekologi, dalam hidupnya burung rangkong merupakan jenis burung yang hidup di kanopi hutan yang paling atas dan tidak pernah di lantai hutan.

\section{Struktur komposisi vegetasi habitat bunga bangkai}

\section{Komposisi spesies dan kelimpahan}

Jumlah total spesies yang menyusun habitat bunga bangkai pada berbagai tingkat permudaan (pohon, tiang, pancang, dan semai) adalah 417 spesies yang tergolong ke dalam 103 famili. Hasil penelitian menunjukkan bahwa lima famili yang paling banyak jumlah spesiesnya adalah famili Lauraceae (27 spesies), Moraceae (22 spesies), Annonaceae (21 spesies), Euphorbiaceae (20 spesies), Phyllanthaceae (20 spesies) (Gambar 4).

30

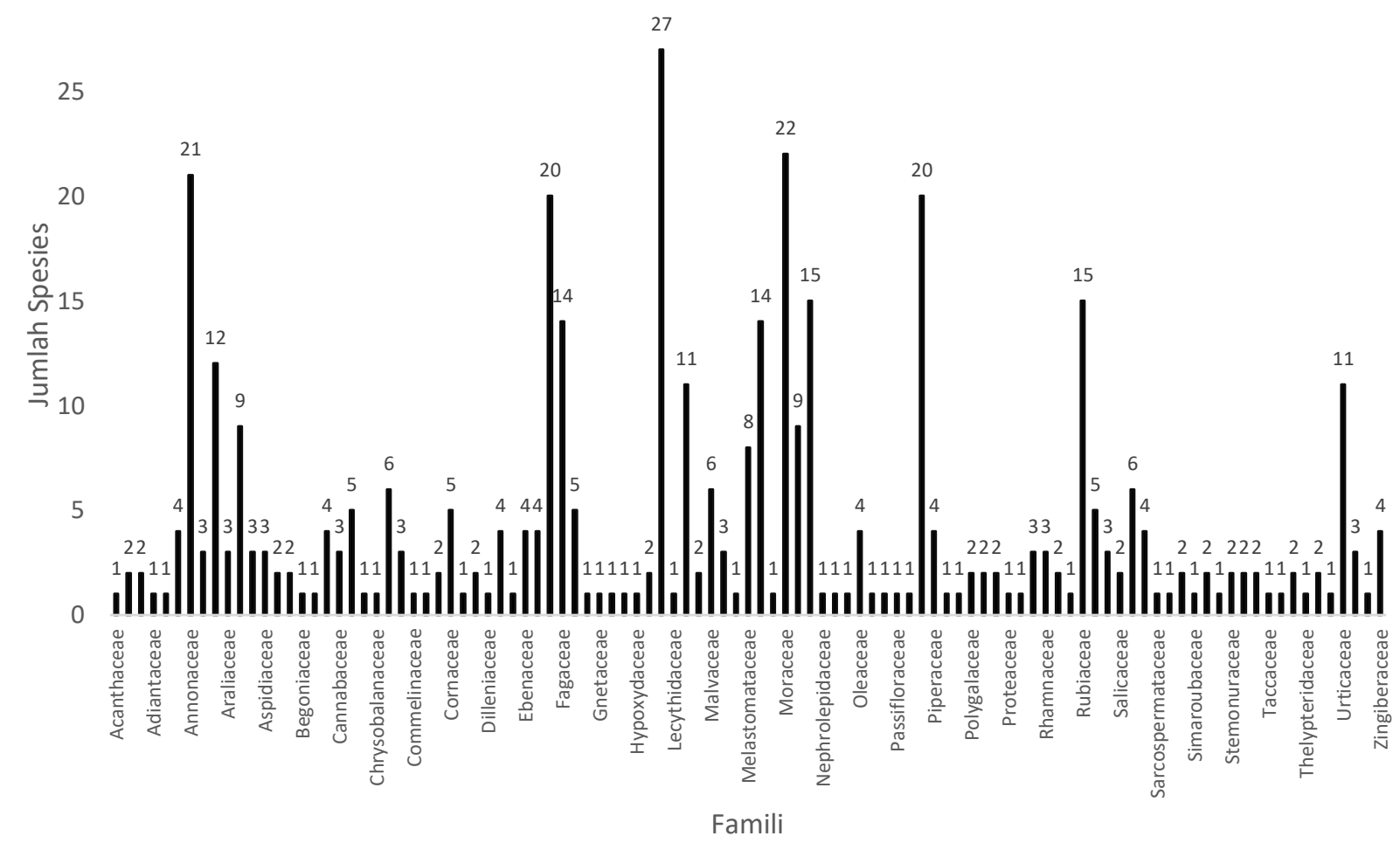

Gambar 4 Jumlah jenis setiap famili tumbuhan di 3 lokasi habitat bunga bangkai 
Selanjutnya, Whitmore dan Sidiyasa (1986) menyatakan bahwa, pada plot ukuran kecil di Kalimantan dan Sumatera, famili Lauraceae merupakan salah satu famili yang mempunyai jumlah spesies paling banyak. Jika dilihat kelimpahan spesies menurut familinya, kondisi ini mencirikan vegetasi hutan dataran rendah. Hasil ini sesuai penelitian Whitten et al. (2000) di Sumatera yang menyatakan bahwa hutan dataran rendah dicirikan oleh keberadaan famili Burseraceae, Sapotaceae, Euphorbiacea, Lauraceae, Myrtaceae, Dipterocarpaceae, Rubiaceae, dan Annonaceae.

Perbedaan jumlah jenis yang ditemukan di 3 lokasi penelitian disebabkan tingkat gangguan terhadap vegetasi hutan. Pada lokasi- lokasi yang kelerenganan ekstrim seperti lokasi Air Selimang tingkat gangguan vegetasi pada habitat bunga bangkai relatif kurang intensitasnya.

Jika dilihat jumlah famili pada setiap lokasi penelitian (Gambar 5), menunjukkan bahwa lokasi Air Selimang mempunyai jumlah famili yang paling banyak pada tingkat pancang (83 famili).

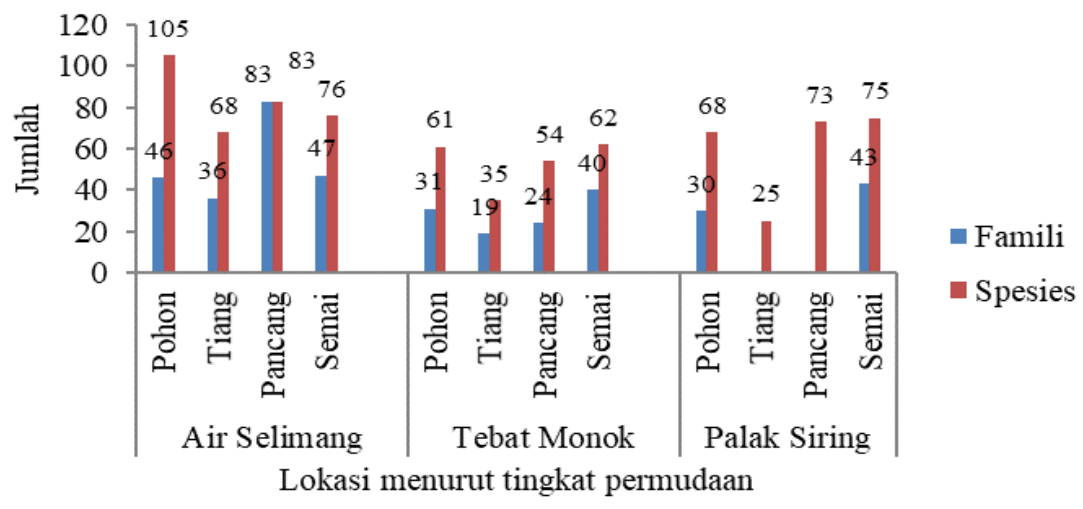

Gambar 5 Jumlah jenis dan famili menurut lokasi penelitian

Struktur vegetasi jika dilihat menurut parameter kerapatan (Gambar 6) menunjukkan bahwa semua tingkatan permudaan mempunyai kecenderungan kerapatan yang relatif berbeda-beda pada setiap lokasi.

Kerapatan yang tertinggi ditemukan pada tingkat semai dan terus menurun ke tingkat pohon. Grafik jumlah individu pada setiap tingkat pertumbuhan (Gambar 6), memperlihatkan kurva berbentuk huruf "J" terbalik. Kondisi ini menunjukkan bahwa hutan berada dalam kondisi normal/seimbang, jumlah individu tingkat semai lebih banyak dari pancang, lebih banyak dari tiang dan lebih banyak dari pohon. Hal ini merupakan gambaran proses regenerasi hutan berlangsung. Lokasi yang mempunyai kerapatan individu tertinggi pada tingkat semai adalah lokasi Palak Siring yaitu 549 individu/3 ha atau 183 individu/ha. Selanjutnya pada urutan kedua ditemukan di lokasi Air Selimang yaitu 421 individu/3 ha atau 140 individu/ha. Pada 3 lokasi penelitian kerapan individu pada tingkat pohon berkisar 115-169 individu pohon/3 ha atau 3856 individu/ha. Vegetasi tingkat tiang (diameter batang $10 \mathrm{~cm}-19 \mathrm{~cm}$ ) mempunyai kisaran kerapatan tingkat tinga pada 3 lokasi penelitian 31-101 individu/3 ha atau 10-34 individu/ha. Jumlah jenis vegetasi tingkat tiang yang ditemukan di habitat bunga bangkai lebih rendah jika di bandingkan hasil penelitian Proctor et al. (1983) di Gunung Mulu Serawak yang mencatat sebanyak 778 individu per hektar. Kondisi ini menggambarkan bahwa kondisi vegetasi di habitat bunga bangkai sudah mengalami gangguan dan kerusakan. 


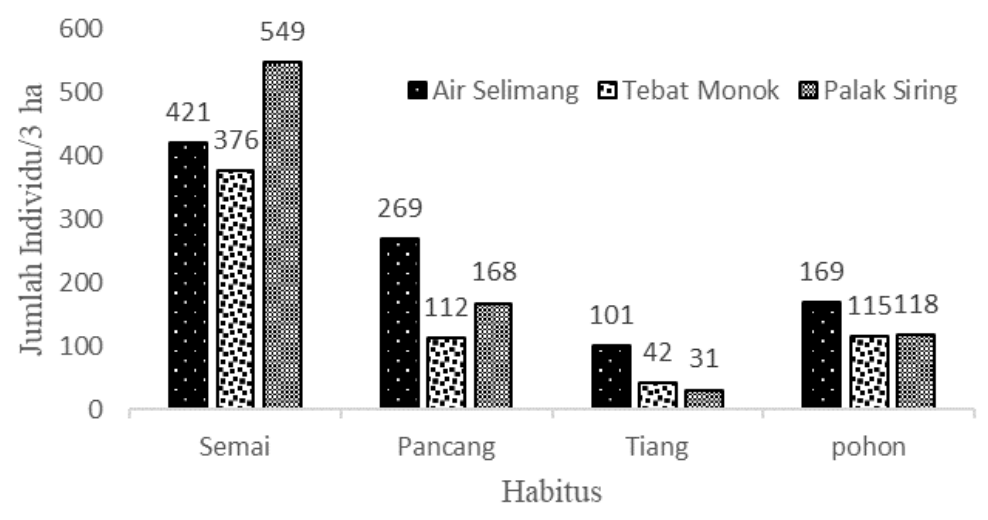

Gambar 6 Kerapatan individu tingkat pohon, tiang, pancang dan semai di 3 lokasi

Struktur vegetasi habitat bunga bangkai jika di lihat dari kelas diameter pohon penyusunan terdapat pada Gambar 7 berikut.

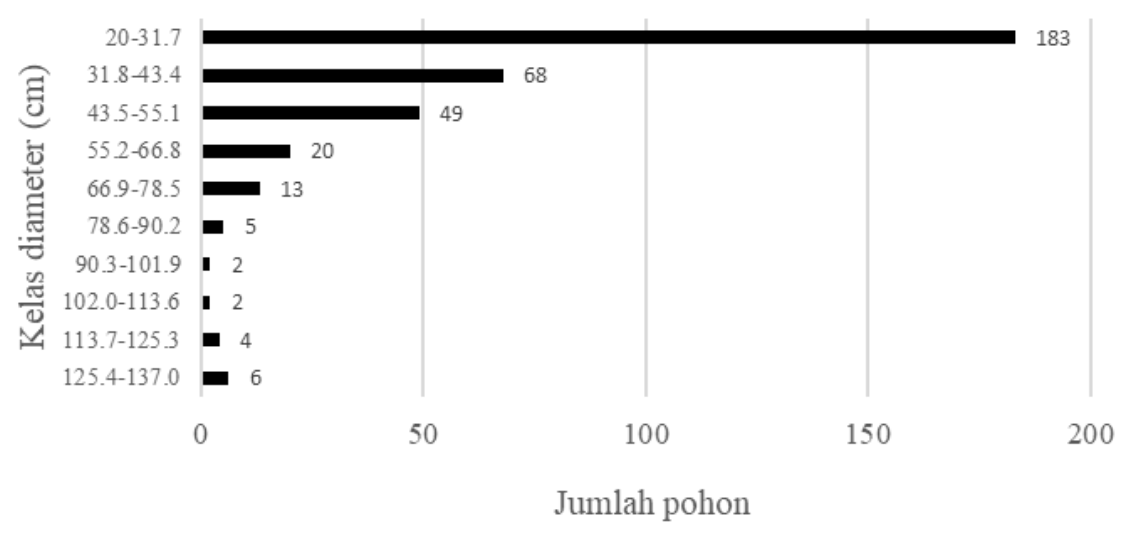

Gambar 7 Distribusi kelas diameter dan jumlah spesies pohon dengan DBH $>20 \mathrm{~cm}$ pada plot ukuran 3 ha.

Berdasarkan Gambar 7, tampak bahwa kelas diameter $20 \mathrm{~cm}-31.7 \mathrm{~cm}$ merupakan kelas diameter batang pohon yang dominan dengan jumlah pohon sebanyak 183 (52\%) batang pohon. Selanjutnya pada urutan kedua ditempati oleh kelas diameter pohon $31.8 \mathrm{~cm}-43.4 \mathrm{~cm}$, yaitu sebanyak $68(19 \%)$ batang pohon. Kelas diameter batang yang paling sedikit jumlah pohonnya adalah diameter $90.3 \mathrm{~cm}-101.9 \mathrm{~cm}$ dan $102.0 \mathrm{~cm}-113.6 \mathrm{~cm}$ masing sebanyak 2 pohon. Pola jumlah pohon menurut kelas diameter relatif hampir sama dengan penelitian Kartawinata et al. (2008) yang menyatakan bahwa pola tersebut lebih kurang merupakan tipikal distribusi kelas diameter pohon pada hutan yang tidak terganggu.

Pada Lokasi Air Selimang, vegetasi tingkat pohon disusun atas 105 spesies yang tergolong ke dalam 46 famili. Spesies tumbuhan yang dominan adalah Artocarpus elasticus (Moracea) dengan indeks nilai penting (INP) $12.09 \%$ (Tabel 3). Vegetasi tingkat tiang disusun atas 68 spesies yang tergolong ke dalam 36 famili. Spesies yang mendominasi pada urutan pertama adalah Oreocnide rubescens dengan INP $22.64 \%$. Vegetasi tingkat pancang disusun atas 83 spesies yang tergolong ke dalam 83 famili. Spesies yang mendominasi pada urutan pertama adalah Pinanga coronata dengan INP 9.48\%. Vegetasi tingkat semai disusun atas 76 spesies yang tergolong ke dalam 47 famili. Spesies yang mendominasi pada urutan pertama adalah Elatostema integrifolium dengan INP 22.44\% (Tabel 3). 
Tabel 3 Lima spesies yang mempunyai Indeks Nilai Penting (INP) tertinggi vegetasi tingkat pohon, tiang, pancang, dan semai di Air Selimang

\begin{tabular}{|c|c|c|c|c|}
\hline Strata & No & Spesies & Famili & $\begin{array}{c}\text { Indeks Nilai } \\
\text { Penting (INP) } \\
(\%)\end{array}$ \\
\hline \multirow[t]{5}{*}{ Pohon } & 1 & Artocarpus elasticus Rienw.ex Blume & Moraceae & 12.09 \\
\hline & 2 & Oreocnide rubescent (Blume) Miq & Urticaceae & 10.02 \\
\hline & 3 & Syzygium pycnanthum Merr.\&L.M.Perry & Myrtaceae & 9.39 \\
\hline & 4 & Pomentia pinnata J.R.Forst.\& G.Frost & Sapindaceae & 9.02 \\
\hline & 5 & Chionanthus cuspidatus Blume & Oleaceae & 8.04 \\
\hline \multirow[t]{5}{*}{ Tiang } & 1 & Oreocnide rubescens (Blume) Miq. & Urticaceae & 22.64 \\
\hline & 2 & Antidesma montanum Blume & Phyllanthaceae & 16.31 \\
\hline & 3 & Quercus oidocarpa Korth & Fagaceae & 9.76 \\
\hline & 4 & $\begin{array}{l}\text { Dendrocnide microstigma ( Gaudich. Ex Wedd.) } \\
\text { Chew }\end{array}$ & Urticaceae & 9.31 \\
\hline & 5 & Garcinia havilandii Stapf & Clusiaceae & 8.79 \\
\hline \multirow[t]{5}{*}{ Pancang } & 1 & Pinanga coronata (Blume ex Mart.) Blume & Arecaceae & 9.48 \\
\hline & 2 & Dendrocnide stimulans (L.f.) Chew & Urticaceae & 7.26 \\
\hline & 3 & Baccaurea parvifloa (Muell. Arg.) Muell. Arg. & Phyllanthaceae & 6.70 \\
\hline & 4 & Aglaia argentea Blume & Meliaceae & 6.15 \\
\hline & 5 & Antidesma montanum Blume & Phyllanthaceae & 5.78 \\
\hline \multirow[t]{5}{*}{ Semai } & 1 & Elatostema integrifolium Wedd. & Urticaceae & 22.44 \\
\hline & 2 & Selaginella willdenowii (Desv. ex Poir.) Baker & Selaginellaceae & 21.55 \\
\hline & 3 & Coffea canephora Pierre. Ex A.Froehner & Rubiaceae & 12.68 \\
\hline & 4 & Homalomena habokoana Alderw & Araceae & 7.28 \\
\hline & 5 & Cyrtandra picta Blume & Gesneriaceae & 6.80 \\
\hline
\end{tabular}

Lokasi Tebat Monok terletak pada ketinggian $656 \mathrm{~m} \mathrm{dpl}-671 \mathrm{~m}$ dpl, dengan kelerengan berkisar 30 $45^{\circ}$. Sebagian lokasi sudah dikonversi menjadi ladang kopi. Berdasarkan hasil penelitian pada lokasi Tebat Monok vegetasi tingkat pohon disusun atas 61 spesies yang termasuk ke dalam 31 famili. Spesies yang mendominasi pada urutan pertama adalah Quercus oidocarpa, dengan indeks nilai penting (INP) $22.22 \%$ (Tabel 4). Pada urutan kedua didominasi oleh Balakata baccata dengan INP 20.65\%. Spesies yang mendominasi pada urutan ketiga adalah Styrax benzoin yaitu dengan indeks nilai penting $19.57 \%$. Spesies yang menempati urutan kelima yang mempunyai INP tertinggi adalah Baccaurea macrocarpa $(11.57 \%)$.

Vegetasi tingkat tiang di lokasi Tebat Monok di susun oleh 35 spesies yang tergolong ke dalam 19 famili. Spesies yang mendominasi pada urutan pertama adalah Styrax benzoin, dengan INP 19.86\% (Tabel 4). Selanjutnya pada urutan kedua didominasi oleh spesies Ficus fulva dengan indeks nilai penting $16.65 \%$. Pada urutan ke tiga vegetasi tingkat tiang didominasi oleh spesies Artocarpus integer (Famili Moraceae) dengan INP 9.76\%. Pada urutan ke-empat didominasi oleh Quercus oidocarpa dengan indeks nilai penting 15.62\%. Selanjutnya pada urutan kelima didominasi oleh spesies Mallotus rufidulus dengan indeks nilai penting $15.04 \%$ (Tabel 4).

Vegetasi tingkat pancang disusun atas 54 spesies yang termasuk ke dalam 24 famili. Spesies yang mendominasi pada urutan pertama adalah Q.oidocarpa, dengan indeks nilai penting (INP) $11.76 \%$. Pada urutan kedua didominasi oleh Memecylon costatum dengan INP 9,97\% dan pada urutan ketiga didominasi oleh M. lowii dengan INP 2.29\%.

Vegetasi tingkat semai di lokasi Tebat Monok di susun oleh 62 spesies yang tergolong ke dalam 40 famili. Spesies yang mendominasi pada urutan pertama adalah S. willdenowii, dengan INP 15.52\%. Selanjutnya pada 
urutan kedua didominasi oleh spesies Nephrolepis exaltata dengan indeks nilai penting $15.21 \%$. Pada urutan ke tiga vegetasi tingkat semai didominasi oleh spesies Styrax benzoin (Famili Styracaceae) dengan INP 13.55\%. Pada urutan ke-empat didominasi oleh Coffea canephora dengan indeks nilai penting 10.89\%. Selanjutnya pada urutan kelima didominasi oleh spesies Homalomena habokoana dengan indeks nilai penting $10.04 \%$.

Lokasi Palak siring terletak pada ketinggian 366-409 mdpl. Hasil penelitian pada lokasi Palak Siring vegetasi tingkat pohon disusun atas 68 spesies yang termasuk ke dalam 30 famili. Spesies yang mendominasi pada urutan pertama adalah Elateriospermum tapos, dengan indeks nilai penting (INP) $31.44 \%$. Pada urutan kedua didominasi oleh Cephalomappa malloticarpa dengan INP 16.05\% (Tabel 5).

Vegetasi tingkat tiang di lokasi Palak Siring di susun oleh 25 spesies. Spesies yang mendominasi pada urutan pertama adalah Cephalomappa malloticarpa, dengan INP 32.76\%. Selanjutnya pada urutan kedua didominasi oleh spesies Elateriospermum tapos dengan indeks nilai penting $31.05 \%$. Pada urutan ke tiga vegetasi tingkat tiang didominasi oleh spesies Aporosa frutescens (Famili Phyllanthaceae) dengan INP $19.70 \%$.

Tabel 4 Lima spesies yang mempunyai Indeks Nilai Penting tertinggi vegetasi tingkat pohon, tiang, pancang dan semai di lokasi Tebat Monok

\begin{tabular}{|c|c|c|c|c|}
\hline Strata & No & Spesies & Famili & $\begin{array}{c}\text { Indeks Nilai } \\
\text { Penting } \\
\text { (INP) } \\
(\%)\end{array}$ \\
\hline \multirow[t]{5}{*}{ Pohon } & 1 & Quercus oidocarpa Korth & Fagaceae & 22.22 \\
\hline & 2 & Balakata baccata (Roxb.) Esser & Euphorbiaceae & 20.65 \\
\hline & 3 & Styrax benzoin Dryand. & Styracaceae & 19.57 \\
\hline & 4 & Gordonia excelsa (Blume) Blume & Theaceae & 13.28 \\
\hline & 5 & Baccaurea macrocarpa (Miq.) Muell. Arg. & Phyllanthaceae & 11.57 \\
\hline \multirow[t]{5}{*}{ Tiang } & 1 & Styrax benzoin Dryland & Styracaceae & 19.86 \\
\hline & 2 & Ficus fulva Reinw.ex Blume & Moraceae & 16.65 \\
\hline & 3 & Artocarpus integer (Thunb.) Merr. & Moraceae & 15.90 \\
\hline & 4 & Quercus oidocarpa Korth. & Fagaceae & 15.62 \\
\hline & 5 & Mallotus rufidulus (Miq.) Muell. Arg. & Euphorbiaceae & 15.04 \\
\hline \multirow[t]{5}{*}{ Pancang } & 1 & Quercus oidocarpa Korth. & Fagaceae & 11.76 \\
\hline & 2 & Memecylon costatum Miq. & Melastomataceae & 9.97 \\
\hline & 3 & Macaranga lowii King ex Hook.f. & Euphorbiaceae & 7.29 \\
\hline & 4 & Pinanga coronata (Blume ex Mart.) Blume & Arecaceae & 6.90 \\
\hline & 5 & Coffea canephora Pierre ex A.Froehner & Rubiaceae & 6.00 \\
\hline \multirow[t]{5}{*}{ Semai } & 1 & Selaginella willdenowii (Desv. ex Poir.) Baker & Selaginellaceae & 15.52 \\
\hline & 2 & Nephrolepis exaltata (L.) Schott & Nephrolepidaceae & 15.21 \\
\hline & 3 & Styrax benzoin Dryand. & Styracaceae & 13.55 \\
\hline & 4 & Coffea canephora Pierre ex A.Froehner & Rubiaceae & 10.89 \\
\hline & 5 & Homalomena habokoana Alderw & Araceae & 10.04 \\
\hline
\end{tabular}

Vegetasi tingkat pancang di lokasi Palak Siring di susun oleh 73 spesies. Spesies yang mendominasi pada urutan pertama adalah Cephalomappa malloticarpa, dengan INP 10.76\%. Selanjutnya pada urutan kedua didominasi oleh spesies Polyalthia lateriflora dengan indeks nilai penting 9.95\%. Pada urutan ke tiga vegetasi tingkat pancang didominasi oleh spesies Elateriospermum tapos (Famili Euphorbiaceae) dengan INP 9.36\%. 
Pada urutan ke-empat didominasi oleh Microcos florida dan Cleistanthus myrianthus yang masing-masing mempunyai indeks nilai penting $8.17 \%$.

Vegetasi tingkat semai disusun oleh 75 spesies yang termasuk kedalam 43 famili. Spesies yang mendominasi pada urutan pertama adalah Selaginella plana dengan indeks nilai penting $53.82 \%$. Jenis ini merupakan indikator daerah yang mempunyai Kelembaban yang relatif tinggi. Selanjutnya pada urutan kedua didominasi oleh Schismatoglottis calyptrata dengan INP sebesar 15.98\%. Pada urutan ketiga, didominasi oleh Homalomena habokoana dengan indeks nilai penting (INP) 10.78\%. Relatif banyaknya spesies dari famili Araceae ini merupakan indikator kondisi tempat tumbuh relatif lebih lembab. Pada urutan kelima, spesies tumbuhan tingkat semai didominasi oleh Cyrtandra picta dengan INP 6.53\%. Hasil yang sama juga dilaporkan oleh Hidayat dan Yuzammi (2008), bahwa jenis tumbuhan bawah yang sering ditemui disekitar bunga bangkai adalah Selaginella wildenowii, Nephrolepis biserrata, Colocosia gigantean dan Globa pendula.

Tabel 5 Lima spesies yang mempunyai Indeks Nilai Penting tertinggi vegetasi tingkat pohon, tiang, pancang dan semai di lokasi Palak Siring

\begin{tabular}{|c|c|c|c|c|}
\hline Strata & $\mathrm{NO}$ & Jenis & Suku & $\begin{array}{l}\text { Indeks Nilai } \\
\text { Penting } \\
\text { (INP) }(\%)\end{array}$ \\
\hline \multirow[t]{5}{*}{ Pohon } & 1 & Elateriospermum tapos Blume & Euphorbiaceae & 31.40 \\
\hline & 2 & Cephalomappa malloticarpa J.J Smit & Euphorbiaceae & 16.05 \\
\hline & 3 & Diospyros sumatrana Miq. & Ebenaceae & 15.95 \\
\hline & 4 & Microcos florida Burret & Malvaceae & 11.82 \\
\hline & 5 & Ficus drupacea Thunb. & Moraceae & 10.80 \\
\hline \multirow[t]{5}{*}{ Tiang } & 1 & Cephalomappa malloticarpa J.J.Sm. & Euphorbiaceae & 32.76 \\
\hline & 2 & Elateriospermum tapos Blume & Euphorbiaceae & 31.05 \\
\hline & 3 & Aporosa frutescens Blume & Phyllanthaceae & 19.70 \\
\hline & 4 & Oreocnide rubescens (Blume) Miq. & Urticaceae & 16.75 \\
\hline & 5 & Phoebe grandis (Nees.) Merr. & Lauraceae & 13.42 \\
\hline \multirow[t]{5}{*}{ Pancang } & 1 & Cephalomappa malloticarpa J.J.Sm. & Euphorbiaceae & 10.76 \\
\hline & 2 & Polyalthia lateriflora (Blume) Kurz. & Annonaceae & 9.95 \\
\hline & 3 & Elateriospermum tapos Blume & Euphorbiaceae & 9.36 \\
\hline & 4 & Microcos florida Burret & Malvaceae & 8.17 \\
\hline & 5 & Cleistanthus myrianthus Kurz. & Phyllanthaceae & 8.17 \\
\hline \multirow[t]{5}{*}{ Semai } & 1 & Selaginella plana (Desv. ex Poir.) Hieron. & Selaginellaceae & 53.82 \\
\hline & 2 & $\begin{array}{l}\text { Schismatoglottis calyptrata (Roxb.) Zoll. \& } \\
\text { Moritzi }\end{array}$ & Araceae & 15.98 \\
\hline & 3 & Homalomena habokoana Alderw & Araceae & 10.78 \\
\hline & 4 & Coffea canephora Pierre ex A.Froehner & Rubiaceae & 7.73 \\
\hline & 5 & Cyrtandra picta Blume & Gesneriaceae & 6.53 \\
\hline
\end{tabular}

\section{Keanekaragaman spesies dan dan kemerataan}

Indeks keanekaragaman pada areal penelitian berkisar 2.75-4.50 (Tabel 6). Indeks keanekaragaman yang tertinggi terdapat dilokasi Air Selimang untuk vegetasi tingkat pohon (4.5), tiang (4.04), dan pancang (4.04). Ludwig dan Reynolds (1988) menyatakan bahwa faktor yang menentukan keanekaragaman ada 2 yaitu jumlah total spesies dan kemerataannya. Hasil penelitian Hidayat dan Yuzammi (2008) menujukkan nilai keanekaragaman pada habitat bunga bangkai di Kepahiang rendah yaitu 1.08-3.21 dan 0.40 -2.81 untuk daerah Datar Lebar. Selanjutnya Magurran (1988) mengatakan bahwa salah satu masalah dengan ukuran 
keanekaragaman adalah ukuran dan intensitas sampel sangat mempengaruhi kekayaan spesies. Indek kemerataan untuk tingkat pohon sampai dengan semai di 3 lokasi relatif tinggi dan berkisar $0.640-0.982$ (Tabel 6). Indeks kemerataan yang paling kecil ditemukan pada vegetasi tingkat semai di Palak Siring. Nilai ini menggambarkan bahwa spesies-spesies pohon, tiang, pancang, dan semai hampir tersebar merata pada seluruh plot pengamatan. Nilai indeks kemerataan yang tertinggi pada tingkat pohon ditemukan di Air Selimang yaitu 0.960. Nilai indeks kemerataan sangat dipengaruhi oleh nilai kekayaan spesies.

\section{Asosiasi interspesifik (banyak Spesies)}

Habitat bunga bangkai di Air Selimang dan Tebat Monok mempunyai asosiasi positif pada seluruh spesies. Kondisi ini menunjukkan bahwa antar spesies di lokasi Air Selimang dan Tebat Monok terdapat ketergantungan dan penggunaan sumber daya yang sama bersifat positif.

Tabel 6 Indeks keanekaragaman dan kemerataan vegetasi tingkat pohon, tiang, pancang dan semai pada 3 lokasi habitat bunga bangkai.

\begin{tabular}{lccc}
\hline Lokasi & Strata & Indeks keanekaragaman & Indek kemerataan \\
\hline Air Selimang & Pohon & 4.50 & 0.960 \\
& Tiang & 4.04 & 0.958 \\
& Pancang & 4.04 & 0.915 \\
& Semai & 3.48 & 0.802 \\
\hline Tebat Monok & Pohon & 3.89 & 0.947 \\
& Tiang & 3.49 & 0.982 \\
& Pancang & 3.77 & 0.946 \\
& Semai & 3.41 & 0.826 \\
\hline Palak Siring & Pohon & 3.88 & 0.920 \\
& Tiang & 3.14 & 0.974 \\
& Pancang & 4.00 & 0.932 \\
& Semai & 2.76 & 0.640 \\
\hline
\end{tabular}

Tabel 6 Asosiasi interspesifik komunitas pada 3 lokasi habitat bunga bangkai

\begin{tabular}{cccc}
\hline No & Lokasi & $\begin{array}{c}\text { Indeks Asosiasi antar } \\
\text { seluruh spesies (VR) }\end{array}$ & Kesimpulan \\
\hline 1 & Air Selimang & 1.59 & Terdapat asosiasi positif pada seluruh \\
spesies
\end{tabular}

Vegetasi di lokasi Palak Siring mempunyai indeks asosiasi antar spesies (VR) 0.96 yang berarti semua spesies independen, namun jika dilihat per spesies masih terdapat asosiasi positif. Secara umum asosiasi interspesifik antara spesies terjadi karena spesies memilih dan menghindari habitat yang sama atau faktor habitat sama dan mereka mempunyai persamaan faktor abiotik dan biotik (Ludwig dan Reynolds 1988). Menurut Barbour et al. (1987) Asosiasi suatu tumbuhan dicirikan oleh komposisi floristik yang relatif konsisten, fisiognomi yang relatif seragam dan terdapat pada habitat yang sama.

Jika dilihat per spesies masih terdapat asosiasi posisitf terutama untuk spesies Harpullia arborea (Blanco) Radlk, Mitrephora rufescens Ridley, Bhesa paniculata Arn, Santiria oblongifolia Blume, dan Baccaurea lanceolata (Miq.) Muell. Arg. Menurut Barbour et al. (1987), asosiasi suatu tumbuhan dicirikan oleh komposisi floristik yang relatif konsisten,fisiognomi yang relatif seragam dan terdapat pada habitat yang sama. 


\section{Kemiripan vegetasi antar lokasi}

Analisis pengelompokkan merupakan teknik klasifikasi untuk menempatkan karakter/sifat yang mirip kedalam kelompok yang sama. Berdasarkan hasil analisis menunjukkan pada jarak kesamaan 68.28 vegatasi habitat bunga bangkai masih dikelompokkan atas 3 tipe vegetasi yang berbeda. Pada jarak kesamaan 62.26, vegetasi Air Selimang menjadi satu kelompok dengan vegetasi Tebat Monok. Pengelompokkan ini berarti, lokasi Air Selimang dan Tebat Monok mempunyai kemiripan vegetasi satu sama lain, sedang untuk lokasi Palak siring, vegetasinya berbeda. Ini menujukkan bahwa habitat bunga bangkai di lokasi Air Selimang dan Tabat Monok relatif hampir mirip. Kondisi ini disebabkan jarak antar 2 lokasi tersebut relatif berdekatan $(12.20 \mathrm{~km})$, jika dibandingankan dengan lokasi Palak Siring. Selanjutnya pada jarak kemiripan 52.42, vegetasi Palak siring menyatu dengan vegetasi Air Selimang dan vegetasi Tabat Monok.

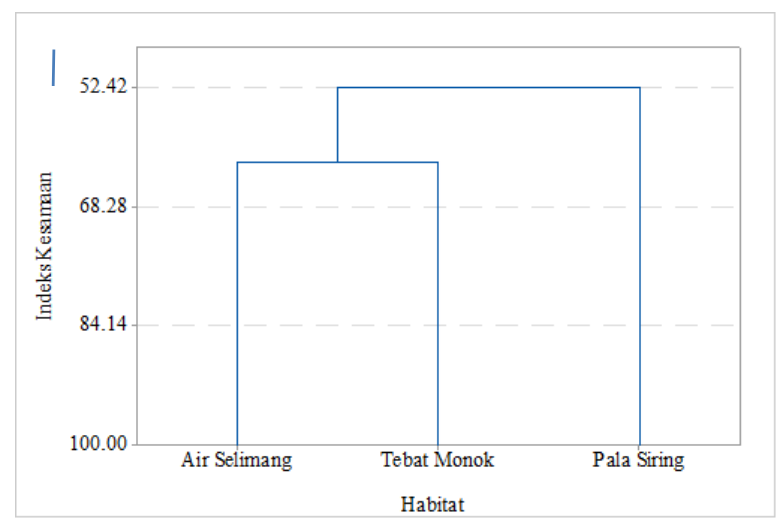

Gambar 8 Dendrogram pengelompokkan 3 komunitas vegetasi habitat bunga bangkai

Pada indeks kesamaan 62.26\%, vegetasi Air Selimang menjadi satu kelompok dengan vegetasi Tebat Monok. Pengelompokkan ini berarti, lokasi Air Selimang dan Tebat Monok mempunyai kemiripan vegetasi satu sama lain, sedang untuk lokasi Palak siring vegetasinya berbeda.

\section{SIMPULAN}

Jumlah total individu bunga bangkai di 3 lokasi penelitian adalah 52 individu, yang terdiri atas 49 individu (fase vegetatif) dan 3 individu ditemukan pada fase generatif. Seluruh populasi bunga bangkai mempunyai pola sebaran mengelompok. Jumlah total spesies yang menyusun habitat bunga bangkai pada berbagai tingkat permudaan (pohon, tiang,pancang, dan semai) adalah 417 spesies yang tergolong ke dalam 103 famili.

Spesies tumbuhan tingkat pohon yang mendominasi di Air Selimang adalah Artocarpus elasticus (Moracea) dengan indeks nilai penting (INP) 12.09\%. Vegetasi tingkat tiang didominasi oleh Oreocnide rubescens (INP 22.64\%), vegetasi tingkat pancang didominasi oleh Pinanga coronata dengan INP 9.48\%. dan Vegetasi tingkat semai oleh Elatostema integrifolium dengan INP $22.44 \%$.

Vegetasi tingkat pohon di Tebat Monok didominasi oleh Quercus oidocarpa, dengan indeks nilai penting (INP) 22.22\%, tingkat tiang didominasi oleh Styrax benzoin (INP 19.86\%). Vegetasi tingkat pancang didominasi oleh Q.oidocarpa, (INP 11.76\%) dan tingkat semai didominasi oleh Selaginella willdenowii dengan INP $15.52 \%$.

Pada lokasi Palak Siring, vegetasi tingkat pohon didominasi oleh Elateriospermum tapos (INP 31.44\%.). Vegetasi tingkat tiang didominasi oleh Cephalomappa malloticarpa (INP 32.76\%) dan pancang didominasi oleh Cephalomappa malloticarpa, (INP 10.76\%). Vegetasi tingkat semai didominasi oleh Selaginella plana (INP 53.82\%).

Habitat bunga bangkai di Air Selimang dan Tebat Monok mempunyai asosiasi positif pada seluruh spesies sedangkan Palak Siring semua spesies asosiasinya saling bebas. Vegetasi bunga bangkai Air Selimang mempunyai kemiripan yang besar dengan Tebat Monok. 


\section{DAFTAR PUSTAKA}

Anonim. 2017. Activated Carbon Filter. Tersedia pada: http://www.waterprofessionals.com/learningcenter/activated-carbon-filters; [diakses 22 October 2017].

Arianto W, Deselina Y, Ridwan. 1999. Keanekaragaman Spesies-Spesies Bunga Bangkai (Amorphophallus Bl) dan Pola Distribusinya di Provinsi Bengkulu. Jakarta: Direktorat Pembinaan Penelitian dan Pengabdian Pada Masyarakat Direktorat Jenderal Pendidikan Tinggi, Departemen Pendidikan dan Kebudayaan.

Barbour MG, Burk JH, Pitts WD. 1987. Terrestrial Plant Ecology. Menlo Park (AS): The Benjamin/Cummings Publishing Company, Inc.

Barthlott W, Lobin W. 1998. Amorphophallus titanum. Akademie Der Wissenchaften Ind Der Literatur.

Barthlott W, Szarzynski J, Vlek P, Lobin W, Korotkova N. 2009. A Torch in the rain forest : thermogenesis of Titan Arum (Amorphophallus titanum). Plant Biol. 11(4): 499-505. doi : 10.11111/J.1438-8677.

Bown D. 1988. Aroids. Plants of The Arun Family. London. Century.

Claudel C, Mangelsdorff RD, Hetterscheid WLA. 2012. The first successful hybrid of Amorphophallus titanum. Aroideana. 35:.81-85.

Fujioka K, Shirasu M, Manome Y, Ito N, Kakishima S, Minami T, Tominaga T, Shimozono F, Iwamoto T, Ikeda K, Yamamoto K, Murata J, and Tomizawa Y. 2012. Objective Display ang Discrimination of floral from Amorphophallus tita-num. bloomed on different dates and at different location using an electronic nose. Sensor. 12: 2152-2161. doi:3390/s12022152.

Gandawijaja D, Idris S, Nasution R, Nyman L P, Ardititi J. 1983. Amorphophallus titanum Becc: Historical Review and Some Recent Observation. Am. Bot. 51: 269-278.

Giordano C. 1999. Karyological and Palynological Observation on Amorphophallus titanum (Becc.) Becc. Ex Arcangeli. International Journal of Cytology, Cytosystematics and Cytogenetics 52 (1-2): 65-73.

Graham C, Hadiah JT. 2004. Amorphophallus titanum Becc. Eksplorasi. 4(2): 12-15.

Hejnowicz Z, Barthlott W. 2005. Structural and mechanical peculiarities of the petioles of giant leaves of Amorphophallus (Araceae). American Journal of Botany. 92(3): 391-403.

Hetterscheid WLA, Ittenbach S. 1996. Everything you always wanted to know about Amorphophallus. but were afraid to stick your nose into. Aroideana. 19: 7-131.

Hidayat S, Yuzammi. 2008. Kajian populasi alami bunga bangkai (Amorhophallus titanum (Becc.) Becc: Studi kasus di kawasan hutan Bengkulu. Buletin Kebun Raya Indonesia.11(1): 9-15.

Hutchinson, GE. 1953. The Concept of Pattern in Ecology. Philadelphia: Proceedings Academy Natural Science.

Irawati. 2011. Micropropagation of Amorphophallus titanum Becc. (Araceae). Buletin Kebun Raya. 14(1): 2936.

Kartawinata K, Purwaningsih, Partomihardjo T, Yusuf R, Abdulhadi R, Riswan S. 2008. Floristic and Structure of A Lowland Dipterocarp Forest at Wanariset Samboja, East Kalimantan. Reinwardtia. 12: 301-323.

Kementerian Kehutanan. 2014. Statistik Kementerian Kehutanan Tahun 2013. Jakarta: Kementerian Kehutanan.

Latifah D, Purwantoro RS. 2015. Perkecambahan biji bunga bangkai Raksasa Amorphophallus titanum (Becc.) Becc ex Ar-cang: Pengarus testa. Berita Biologi. 14(1):39-47.

Lobin W, Neumann N, Radscheit M, Barthlott W. 2007. Cultivation of Titan Arum (Amorphophallus titanum)A Flag ship Species For Botanic Gardens. Sibbaldia The Journal of Botanic Garden Horticulture. 5: 69-86.

Ludwig JA, Reynolds JF. 1988. Statistical Ecology: A Primer on Methods and Computing. Canada: John Wiley \& Sons. Inc.

Magurran AE. 1988. Ecological Diversity and Its Measurement. Princeton: Princeton University Press. 
Mcnaughton SJ, Wolf LL. 1990. Ekologi Umum (Edisi ke-2). Pringoseputro S, Srigandono B, penerjemah, Soedarsono, editor.Yogyakarta: Gadjah Mada University Press. Terjemahan dari: General Ecology. Second edition.

Mueller-Dombois D, Ellenberg H. 1974. Aims and Methods of Vegetation Ecology. New York: John Wiley \& Sons.

Peraturan Pemerintah Republik Indonesia Nomor 7 Tahun 1999 Tentang Pengawetan Jenis Tumbuhan Dan Satwa. Tanggal 27 Januari 1999.

Poerba YS, Yuzammi. 2008. Pendugaan keragaman Genetik Amorphophallus titanum Becc. Berdasarkan Marka Random Amplified Polymorphic DNA. Biodiversitas. 9(2): 103-107.

Poonswad P, Kemp A, Strange M. 2013. Hornbills of The World A Photographic Guide. Draco Publishing and Distribution Pte.Ltd and Hornbill Research Foundation.

Poonswad P. 1998. The Asian Hornbills: Ecology and Conservation (Edited). Biodiversity Research and Training Program National Center for Genetic Engineering and Biotechnology.

Proctor J, Anderson JM, Chai P, Vallack HW. 1983. Ecological studies in four constrasting rain forest in Gunung Mulu National Park, Sarawak: I. Forest Environmental, Structure and Floristic. J. Ecol. 71: 237-60.

Purwantoro, RS, Latifah D. 2013. Ex situ conservation of Amorphophallus titanum (Becc.) Becc: Propagation by leaf Cuttings. Internationa Conference on Global Resource Conservation \& 10th Indonesian Society for Plant Taxonomy Congress Brawijawa University.

Romersburg HC. 1984. Cluster Analysis for Researchers. Belmont: Lifetime Learning Publication.

Sholihin R, Purwantoro RS. 2005. Pertumbuhan Vegetatif pada Amorphophallus titanum (Becc) Becc di Kebun Cibodas. Biodiversitas. 6(3): 190-193.

Whitmore, T.C., Sidiyasa K.1986. Composition and Structure of Lowland Rain Forest at Torout Northen Sulawesi. Kew Bulletin. 41: 747-756.

Whitten T, Damanik SJ, Anwar J, Hisyam N. 2000. Ecology of Sumatra. Hongkong: Periplus Edition (HK) Ltd.

Yuzammi, Kurniawan A, Asih NPS, Erlinawati I, Hetterscheid. 2017. The Amorphophallus of Indonesia. Bogor: Center for Plant Conservation-Botanic Gardens, Indonesia Institute of Science (LIPI). 